\title{
Response of littoral macrophytes to water level fluctuations in a storage reservoir
}

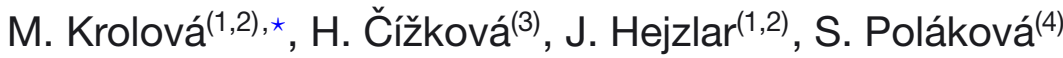 \\ Received October 11, 2012 \\ Revised January 4, 2013 \\ Accepted February 11, 2013
}

\begin{abstract}
Key-words: Lakes and reservoirs that are used for water supply and/or flow regulations ecophases, eulittoral, European Water Framework Directive, littoral macrophytes, water level fluctuation have usually poorly developed littoral macrophyte communities, which impairs ecological potential in terms of the EU Water Framework Directive. The aim of our study was to reveal controlling factors for the growth of littoral macrophytes in a storage reservoir with fluctuating water level (Lipno Reservoir, Czech Republic). Macrophytes occurred in this reservoir only in the eulittoral zone i.e., the shoreline region between the highest and the lowest seasonal water levels. Three eulittoral sub-zones could be distinguished: the upper eulittoral with a stable community of perennial species with high cover, the middle eulittoral with relatively high richness of emergent and amphibious species present at low cover values, and the lower eulittoral devoid of permanent vegetation. Cover and species composition in particular sub-zones were primarily influenced by the duration and timing of flooding, followed by nutrient limitation and strongly reducing conditions in the flooded organic sediment. Our results stress the ecological importance of eulittoral zone in reservoirs with fluctuating water levels where macrophyte growth can be supported by targeted management of water level, thus helping reservoir managers in improving the ecological potential of this type of water bodies.
\end{abstract}

\section{ABSTRACT}

\section{RÉSUMÉ}

\section{Réponse des macrophytes littoraux aux fluctuations du niveau d'eau dans un réservoir}

Mots-clés:
écophases,
eulittoral,
DCE,
macrophytes
littoraux,
fluctuation
du niveau d'eau

Les lacs et réservoirs qui sont utilisés pour l'approvisionnement en eau et/ou les régulations d'écoulement ont généralement des communautés littorales de macrophytes peu développées, ce qui altère le potentiel écologique selon la directive européenne cadre sur l'eau. Le but de notre étude était de révéler les facteurs de contrôle de la croissance des macrophytes littoraux dans un réservoir avec un niveau d'eau fluctuant (Lipno, République tchèque). Les macrophytes ne sont présents dans ce réservoir que dans la zone eulittorale i.e., la région du littoral entre les plus hauts et les plus bas niveaux d'eau saisonniers. Trois sous-zones eulittorales peuvent être distinguées : la eulittorale supérieure avec une communauté stable d'espèces pérennes avec un fort recouvrement, la eulittorale médiane avec

(1) University of South Bohemia, Faculty of Science, Branišovská 31, 37005 České Budějovice, Czech Republic (2) Biology Centre of the AS CR, Institute of Hydrobiology, Na Sádkách 7, 37005 České Budějovice, Czech Republic

(3) CzechGlobe - Global Change Research Centre AS CR, Bělidla 986/4a, 60300 Brno, Czech Republic

(4) Daphne CZ - Institute of Applied Ecology, Emy Destinové 395, 37005 České Budějovice, Czech Republic

* Corresponding author: krolovam@seznam.cz 
une richesse relativement élevée d'espèces émergées et amphibies présentant des valeurs de couverture faible, et la eulittorale inférieure de végétation permanente. Couverture et composition des espèces, dans chaque sous-zone, sont principalement influencées par la durée et le moment des inondations, suivis par la limitation en nutriments et des conditions fortement réductrices dans les sédiments organiques inondés. Nos résultats soulignent l'importance écologique de la zone eulittorale dans des réservoirs à niveaux d'eau fluctuants, où la croissance des macrophytes peut être prise en compte par une gestion ciblée du niveau d'eau, ce qui aide les gestionnaires du réservoir à améliorer le potentiel écologique de ce type de plans d'eau.

\section{INTRODUCTION}

Water storage and flood protection reservoirs have been built in large numbers worldwide in countries without large water bodies. Their primary functions are hydropower generation, water supply, flow augmentation, and/or flood protection. These functions bring about marked fluctuations in water level which in turn restrict the development of littoral communities (Lindström, 1973; Baxter, 1977; Moss, 2008). Within the zone of water level fluctuations macrophytes are affected by the mechanical stress of waves and ice (Björk et al., 1972; Vilmundardóttir et al., 2010), and the heating and desiccation in summer and freezing in winter (Blindow, 1992; Coops and Hosper, 2002). When the range of water level fluctuations exceeds the depth of the euphotic zone, submersed macrophyte species actually lose their niche in the aquatic ecosystem (Hill et al., 1998). Water level fluctuations also adversely affect macrophyte growth through erosion and degradation of the substrate due to the washing out of fine particles and nutrient-rich components (Furey et al., 2004). Erosion can be strong in reservoirs compared to lakes because they are young water bodies with as yet unstabilised shores (Baxter, 1977). In addition, Hellsten et al. (1996) and Partanen and Hellsten (2005) have mentioned that the presence and diversity of littoral vegetation in reservoirs depend on the seasonal timing of water level changes, but do not analyse this relation in detail.

Despite these negative factors, favourable conditions for the development of littoral vegetation can occur in the parts of reservoirs more sheltered from mechanical wave action. At such sites the littoral vegetation may cover large parts of the eulittoral zone, delimited by the seasonal maximum and minimum water levels (Hutchinson, 1975; Wetzel, 1983). Although the eulittoral zone is usually sparsely vegetated on those parts of the shore with steep slopes and on exposed shores with intense wave activity, it can be extensive and support the development of macrophytes on the more flat and sheltered parts of the shore (Nilsson and Keddy, 1988; Hellsten and Riihimäki, 1996; Krolová et al., 2012).

A new impulse for the study of coastal and aquatic vegetation in reservoirs has been brought about by the Water Framework Directive of the European Union (Directive 2000/60/EC; WFD) that aims at creating legislative conditions for the improvement of the ecological quality of stagnant and running waters in EU states. In this context, the littoral vegetation is perceived as an ecologically important component of both natural and semi-natural aquatic ecosystems (Carpenter and Lodge, 1986; Moss, 2008). Understanding its dynamics can contribute to the knowledge needed for us to maximize the ecological potential of reservoirs, as defined by the WFD (Directive 2000/60/EC).

The aims of this study are:

(1) to describe the zonation and seasonal changes of the littoral vegetation in a storage reservoir on a model study site of shore without intense erosion by wave activity;

(2) to evaluate the impact of the main environmental factors on the littoral vegetation and reveal how a flooding regime can influence plant species and their dynamics;

(3) to identify the possibilities of how the reservoir management can create favourable conditions for vegetation development in the eulittoral zone and improve ecological quality in terms of the demands of the Water Framework Directive. 


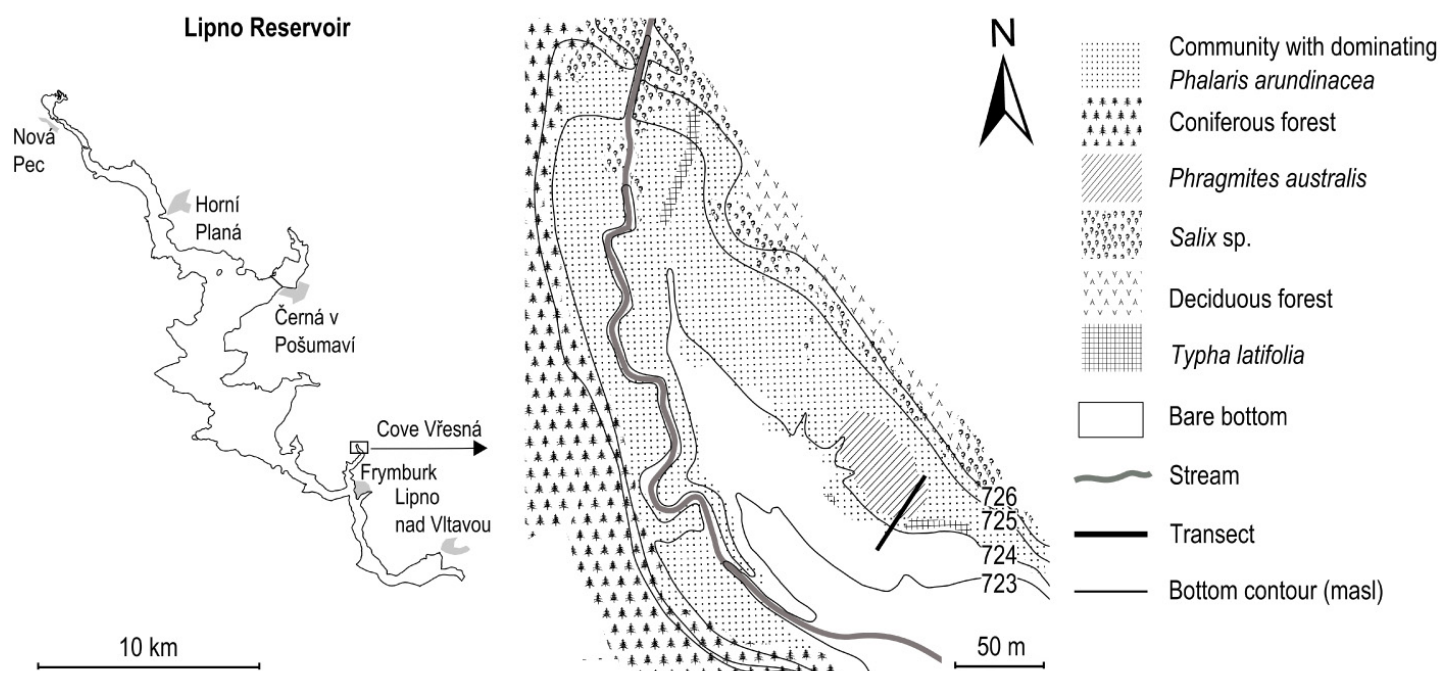

\section{Figure 1}

Map of Vresná bay with distribution of plant communities and the study transect in the eulittoral zone. The legend denotes vegetation types. Herbaceous communities are distinguished according to dominant species, Typha latifolia, Phragmites australis, and Phalaris arundinacea.

\section{METHODS}

\section{> STUDY SITE}

Lipno Reservoir is a river impoundment (total volume: 306 million $\mathrm{m}^{3}$; flooded area: $47 \mathrm{~km}^{2}$; max. depth: $22 \mathrm{~m}$; mean water residence time: $0.6 \mathrm{yr}$ ) situated in South Bohemia, Czech Republic. Since its construction and first filling in 1960 it has been used for hydropower, flood protection, flow augmentation, drinking water abstraction and, largely, recreation. The reservoir storage pool varies due to the fulfilment of these various water demands in an annual cycle, typically with a maximum volume in spring and then with a gradual decrease until winter depending on the contemporary flow conditions, i.e., with decreases in water level by up to $3 \mathrm{~m}$ in dry years but with little or no decrease in wet years. The reservoir is moderately eutrophic with phosphorus as a limiting nutrient (mean total $P: 25 \mu \mathrm{g} \cdot \mathrm{L}^{-1}$; mean/max. chlorophyll-a: 14/28 $\mu \mathrm{g} \cdot \mathrm{L}^{-1}$; mean/max. water transparency: 1.9/2.7 m; data from Povodí Vltavy, State Enterprise, for the 2006-2009 period). For more details see Krolová et al. (2012). The bay of Vřesná (Figure 1; $48^{\circ} 40^{\prime} 43^{\prime \prime} \mathrm{N}, 14^{\circ} 9^{\prime} 48^{\prime \prime} \mathrm{E}$ ) was selected as a model area for the study of littoral macrophyte dynamics. This bay is protected against winds (max. fetch length of $1 \mathrm{~km}$ ) and its shores and bottom have a gentle slope (ca. $\left.1^{\circ}\right)$, which creates conditions for negligible shore erosion and the development of a relatively rich littoral vegetation (Krolová et al., 2012). A transect was established here across the elevation gradient, covering the terrestrial, limosal and littoral ecophases in the sense of Hejný and Segal (1998). Twelve sites were set up along this transect at five-metre intervals and marked with wooden poles (Figures 1 and 2).

\section{$>A P P R O A C H$}

It is widely accepted that the function and species composition of littoral vegetation is related to the depth zonation of the vegetated area, but communication in the field is complicated by usage of different terminologies. In this study, the terminology is based on widely accepted textbooks in limnology (Hutchinson, 1975; Wetzel, 1983), where the vegetated zone between the maximum and the minimum seasonal water levels in water bodies is denoted as eulittoral 


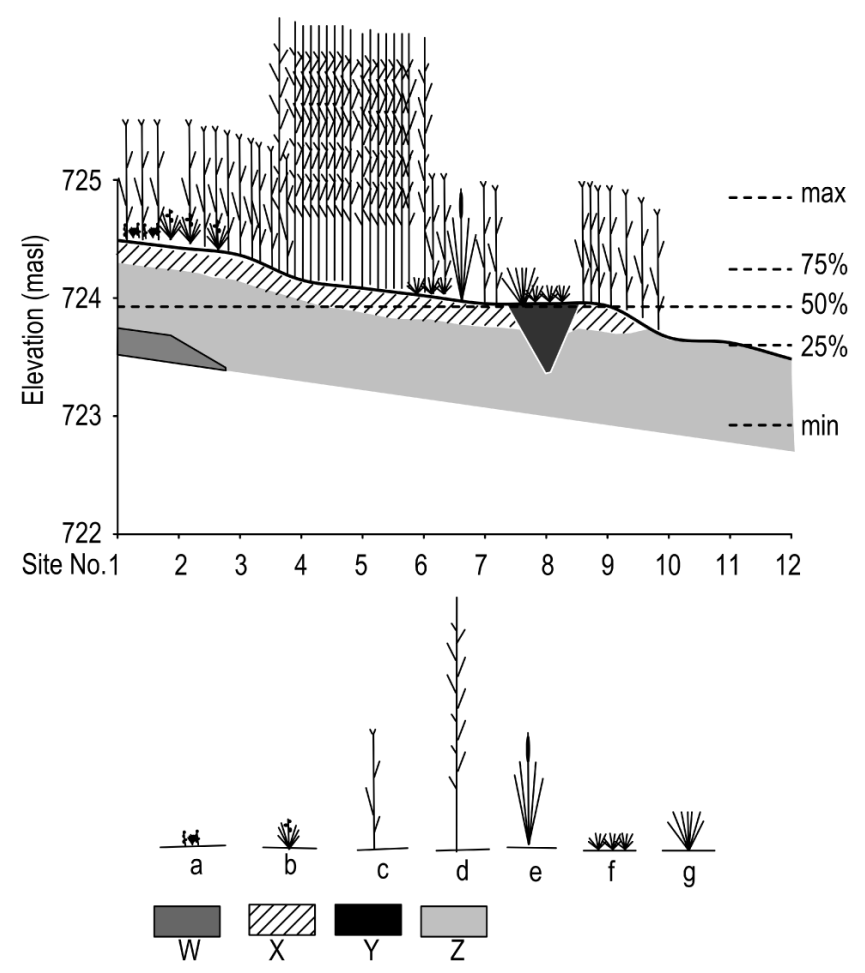

Figure 2

Scheme of elevation gradient in the eulittoral zone of Vresná bay, indicating the presence of dominant plant species. Horizontal lines denote maximum, minimum and selected percentile values of water level in the reservoir within the daily data set of 2006-2009. (a) Terrestrial species; (b) Carex vesicaria; (c) Phalaris arundinacea; (d) Phragmites australis; (e) Typha latifolia; ( $f$ annual species; (g) Sparganium erectum; $W$ - clay; $X$ - rooted organic substrate; $Y$ - sand-silt-clay; $Z$ - partly decomposed organic detritus in silty-clay substrate.

and the permanently flooded vegetated zone as infralittoral. In order to describe the temporal variability of flooding within the eulittoral zone we combine this approach with the concept of ecophases developed in wetland botany by Hejný and Husák (1978) and later modified by Hejný and Segal (1998). An ecophase represents a complex of environmental conditions determined by the current water level at a biotope at a given time. Hejný and Segal (1998) distinguish the following ecophases, determined by the relative position of the surface water level to the bottom level: (1) hydrophase with water level $>1 \mathrm{~m}$ above bottom; (2) littoral ecophase with water level 0.1-1 m above bottom; (3) limosal ecophase with water level near the soil surface (from $0.1 \mathrm{~m}$ above to $0.2 \mathrm{~m}$ below soil surface); and (4) terrestrial ecophase with water level lower than $0.2 \mathrm{~m}$ below the soil surface. The concept of ecophases makes it possible to categorize the current hydrological conditions on particular sites and evaluate the effect of their sequences on the vegetation over time. Using this knowledge, the typical hydrological conditions of a particular wetland habitat can be inferred from the composition of their biotic communities, as long as one knows the biology and ecology of the dominant plants and other biota (Hejný and Husák, 1978; Hejný and Segal, 1998).

\section{>ASSESSMENT OF ENVIRONMENTAL FACTORS}

Water level, soil and water temperatures, and water transparency were measured on all transect sites during the growing seasons (April-October) of 2007-2009 at intervals of 7-14 days. The records of water depth were related to the daily records of surface water level in the reservoir provided by the Povodí Vltavy State Enterprise and used to determine the elevation of the sites. 
Water transparency was assessed in the limosal and littoral ecophases. It was described by a semi-quantitative scale of three grades: 1 - high (details visible throughout the water column including bottom; Secchi dish depth greater than the water depth); 2 - intermediate (details visible in part of the water column, Secchi disk depth similar to the water depth); 3 - low (strong turbidity or scum on the surface, details in the water column not visible, Secchi disk depth smaller than the water depth).

Water and soil temperatures were measured with a portable thermometer at all sites. All measurements were taken between 10 and 12 a.m. In addition, surface soil temperature was continuously recorded at three sites, each with a different position on the elevation gradient (sites 3, 9 and 11), using temperature loggers (TidbiT v2 UTBI-001, Onset, USA). The air temperature and snow cover data originate from the nearby meteorological station of the Czech Hydrometeorological Institute (Černá v Pošumaví; 48 44 $04^{\prime \prime} \mathrm{N}, 14^{\circ} 6^{\prime} 26^{\prime \prime} \mathrm{E}$ ).

On each site, within an area of $1 \mathrm{~m}^{2}$, three samples of substrate were taken in September 2010 , using a soil probe (diameter $2.5 \mathrm{~cm}$ ) to a depth of about $20 \mathrm{~cm}$. All three samples were mixed thoroughly and a representative 0.5 -I sample taken. In addition, the soil profile was described at each site on the basis of samples taken to a depth of $1 \mathrm{~m}$ (Figure 2).

Substrate particle size was determined by dry sieve and wet sedimentation methods (Brady and Weil, 2002; Krolová et al., 2012). Part of the substrate fraction $<2 \mathrm{~mm}$ was freeze-dried and used for determination of total concentrations of $\mathrm{C}, \mathrm{N}, \mathrm{S}$ and P. The C, N and S were determined using a CHNS analyzer (MicroCube, Elementar, Germany) using standard protocol. P was determined spectrophotometricly after nitric-perchloric acid digestion according to Kopáček and Hejzlar (1995).

The redox potential $\left(E_{\mathrm{H}}\right)$ and $\mathrm{pH}$ of the substrate were measured at a $10-\mathrm{cm}$ depth at all sites, repeated three times during a 24-h interval on 12 August 2011, when the water level was at 724.19 meters above sea level (masl). $E_{H}$ was measured with on all sites simultaneously with platinum electrodes (made by EDT, Turnov, Czech Republic) that were individually connected to the high terminals and the reference electrode ( $\mathrm{Ag} / \mathrm{AgCl}$ ) (Dušek et al., 2008). The $\mathrm{E}_{\mathrm{H}}$ values were corrected relative to the normal hydrogen electrode by adding $200 \mathrm{mV}$ (Bochove et al., 2002) and subsequently recalculated to $\mathrm{pH}=7$ using the Nernst equation (Gambrell and Patrick, 1978). $\mathrm{pH}$ was measured using a portable $\mathrm{pH}$-meter equipped with a combined glass electrode (Multi 3400i, WTW, Germany).

\section{> ASSESSMENT OF VEGETATION}

The species composition, cover of individual plant species, and total vegetation cover were recorded for each site on a $1 \times 1 \mathrm{~m}$ permanent square during the growing seasons (AprilOctober) of 2007-2009 at intervals of 7-14 days. The cover of individual plant species was expressed as percentages of total cover for values greater than or equal to $1 \%$. The symbols " $r$ " and "+" were used for species occurring rarely (one small individual per relevé) and not frequently (one robust individual or several small individuals per relevé), respectively. For the statistical analyses (CANOCO, see below) the symbols "r" and "+" were converted to numerical values of $0.01 \%$ and $0.1 \%$, respectively (Van der Maarel, 1979).

The macrophyte species were divided into functional groups according to their preferences for the water environment (hydrophilic terrestrial, emergent, amphibious, floating-leaved, submerged, and free-floating) according to Ellenberg et al. (1992). In addition, the species were assigned to the category of species of bare bottoms, able to colonize exposed bottoms of water bodies during a temporary drawdown (Hejný 1960; Šumberová et al., 2006).

The seasonal development of shoot size was followed using an indirect method derived from the method of standard permanent quadrats (Květ et al. 1998). Three shoots of Phalaris arundinacea and Phragmites australis were randomly chosen within the permanent quadrat on each site and their heights were measured. Each measured shoot was then paired to another shoot of similar size outside the quadrat. The latter shoots were collected and assessed for their length (measured from shoot base to the tip of the highest leaf) and dry weight (determined after drying at $85^{\circ} \mathrm{C}$ ). The measurement was repeated at 14-day intervals during the 
three growing seasons. Their allometric relationships were calculated on the basis of their heights and dry weights, determined after drying to constant weight at $80^{\circ} \mathrm{C}$.

\section{> STATISTICAL ANALYSIS}

The analysis of between-year differences in the flooding of sites along the elevation gradient through the season was done with a generalized linear model (GLM) for binomial distribution (flooded/not flooded). The differences in flooding for the individual sites along the elevation gradient during years were tested using repeated measures ANOVA.

Differences among sites 3, 9 and 11 in soil temperature were assessed using repeated measures ANOVA. Between-year differences in air temperature during the vegetation period (1 April to 31 October) were assessed by a test of interaction of day of the season and year in ANOVA. The same procedure was used for testing differences in air temperature between winter periods (1 November to 31 March). Differences in allometric relationships between seasons and within season for the Phalaris arundinacea and Phragmites australis data were tested by a GLM for Poisson distribution with a log link function. In the case of Phalaris arundicea, terrestrial and limosal growth forms were also taken into consideration. These analyses were carried out in STATISTICA 10.0.

In order to explore the environmental factors shaping the plant community composition, we conducted redundancy analysis (RDA) using CANOCO software (ter Braak and Šmilauer, 2002). The effects of water level, the presence of ecophases, soil temperature on the bottom and total cover of littoral vegetation on the occurrence of littoral macrophytes was tested by the RDA forward selection model. Species data were centered. Because of repeated monitoring of the same plots, the split-plot design was used. The statistical significance was assessed on the basis of a Monte-Carlo permutation test run over 500 iterations, with the use of manual forward selection (Lepš and Šmilauer, 2003).

\section{RESULTS}

\section{> ASSESSMENT OF ENVIRONMENTAL FACTORS}

\section{Flooding regime}

The flooding regime on the sites along the studied elevation gradient of the reservoir littoral varied during the three observation seasons (Figure $3 \mathrm{~A}, \mathrm{~B}$ ) as a result of the different hydrological conditions and reservoir operation in each year. The whole transect was flooded every spring and the upper sites (1-6) gradually went through the littoral and/or limosal to terrestrial ecophases every season, but the low sites (7-12) were exposed to the terrestrial ecophase largely only in 2006 (from August/September to January/February 2007), hardly at all in 2007, and in 2008 only on sites 7-9 (from August/September to March 2009). A statistical test confirmed that the flooding of individual sites along the elevation gradient differed during years (repeated measures ANOVA: $F=1.37 ; d f=575 ; p<0.001$ ). The driest site along the elevation gradient (site 1) was flooded 6\% of the time during the period of 1 January 2006 to 31 December 2009, while sites 7 and 12, located in the middle and lower end of the gradient, were flooded during $46 \%$ and $83 \%$ of the time, respectively.

\section{Water transparency}

High transparency (visible details on the bottom) was present at all sites for most of the time during all three years, except for the summer of 2007 and late summer to autumn of 2009. Intermediate transparency was found at the sites at the low end of the elevation gradient (sites 10-12) in June 2007. The worst (intermediate to low) transparency was on the flooded sites 6-12 from July to September 2009 when a water bloom of cyanobacterium Woronichinia naegeliana occurred in the bay (Figure 3C). 
A)

B)

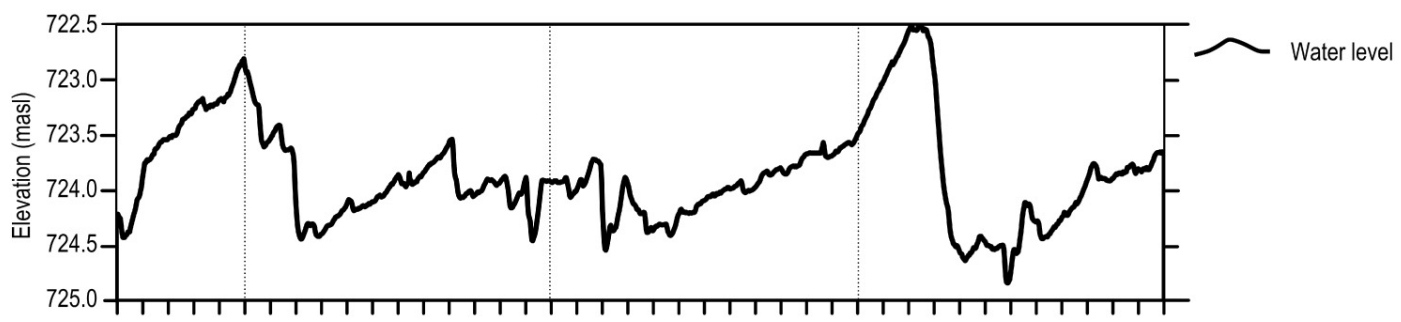

C)
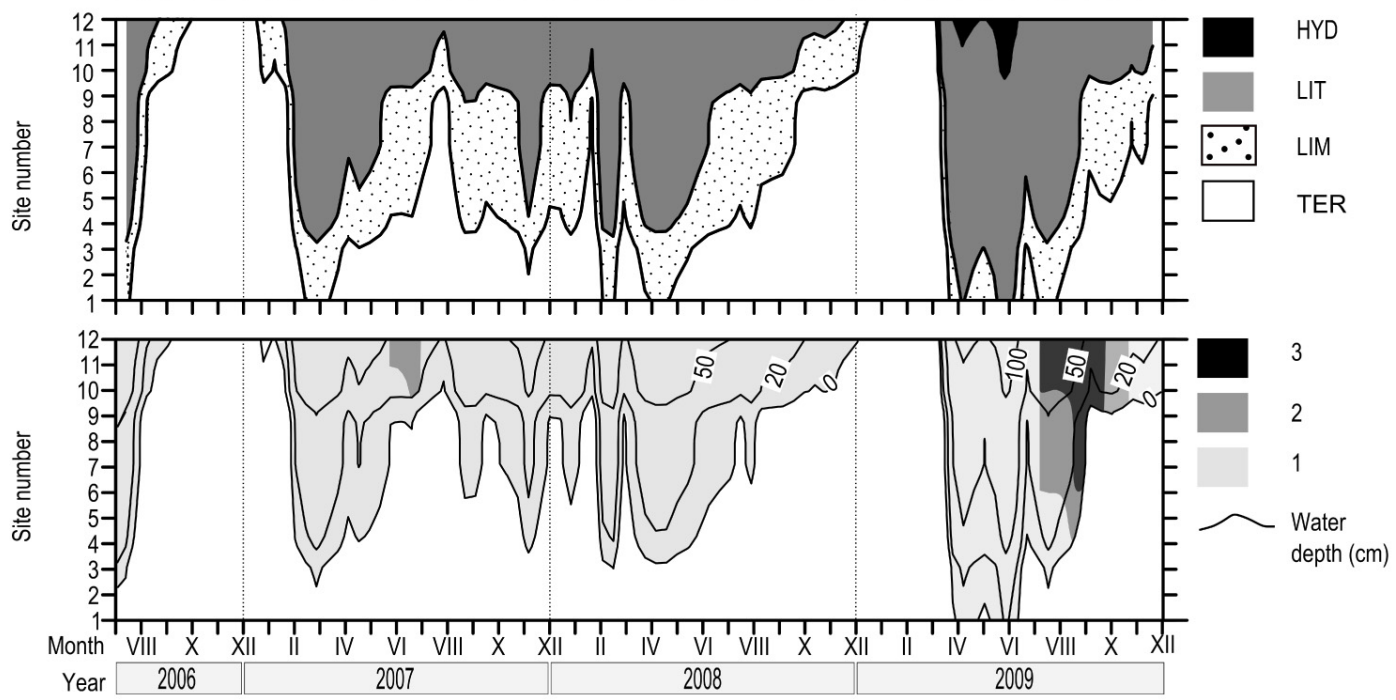

\section{Figure 3}

Water level fluctuation in Lipno Reservoir 2006-2009. (A) Daily water level changes (data by courtesy of Povodí VItavy State Enterprise). (B) Ecophases along the elevation gradient on the study site (TER terrestrial ecophase; LIM - limosal ecophase; LIT - littoral ecophase; HYD - hydrophase). (C) Water transparency: 1 - high transparency (details visible on the bottom); 2 - intermediate transparency (details visible in the water column, Secchi disk at the bottom only partially visible); 3 - low transparency (strong turbidity or scum on the surface, details in the water column not visible, Secchi disk at the bottom not visible).

\section{Temperature}

The course of air temperature did not differ between the vegetation periods of 2007, 2008 and 2009 ( $F=0.37 ; d f=4 ; p=0.8$; Figure 4A). During the growing seasons, all three sites $(9,11$ and 3 ) differed in soil temperatures (Figure 4B; repeated measures ANOVA: $F=913.1$; $D F=2 ; p<0.001$; Tukey HSD test: $p<0.001$ ). In winter, the soil temperature was markedly more stable than the air temperature; it did not decrease below $-5^{\circ} \mathrm{C}$ on any site monitored even if the air temperature declined below $-10^{\circ} \mathrm{C}$ (Figure 4A). The soil thermal stability was due to the presence of snow cover (Figure $4 \mathrm{C}$ ).

The three winter periods differed among themselves in air temperature (repeated measures ANOVA: $F=35.7 ; D F=2 ; p<0.001$; Tukey HSD test: $p<0.001$ ). The winter of 2006-2007 was the warmest of all three years of study. The transect was not flooded and, for most of the time, without snow. In winter 2006-2007, the lower (flooded) part of the transect was covered with ice while the upper part was covered with snow for about half of the winter time. In winter 2008-2009, the transect was not flooded, but was covered with snow for most of the time (Figure 4C). Similarly as in the growing season, the soil temperature was higher on site 11 when it was covered with a shallow water column as compared with exposed sites 9 and 3 (Figure 4B). 

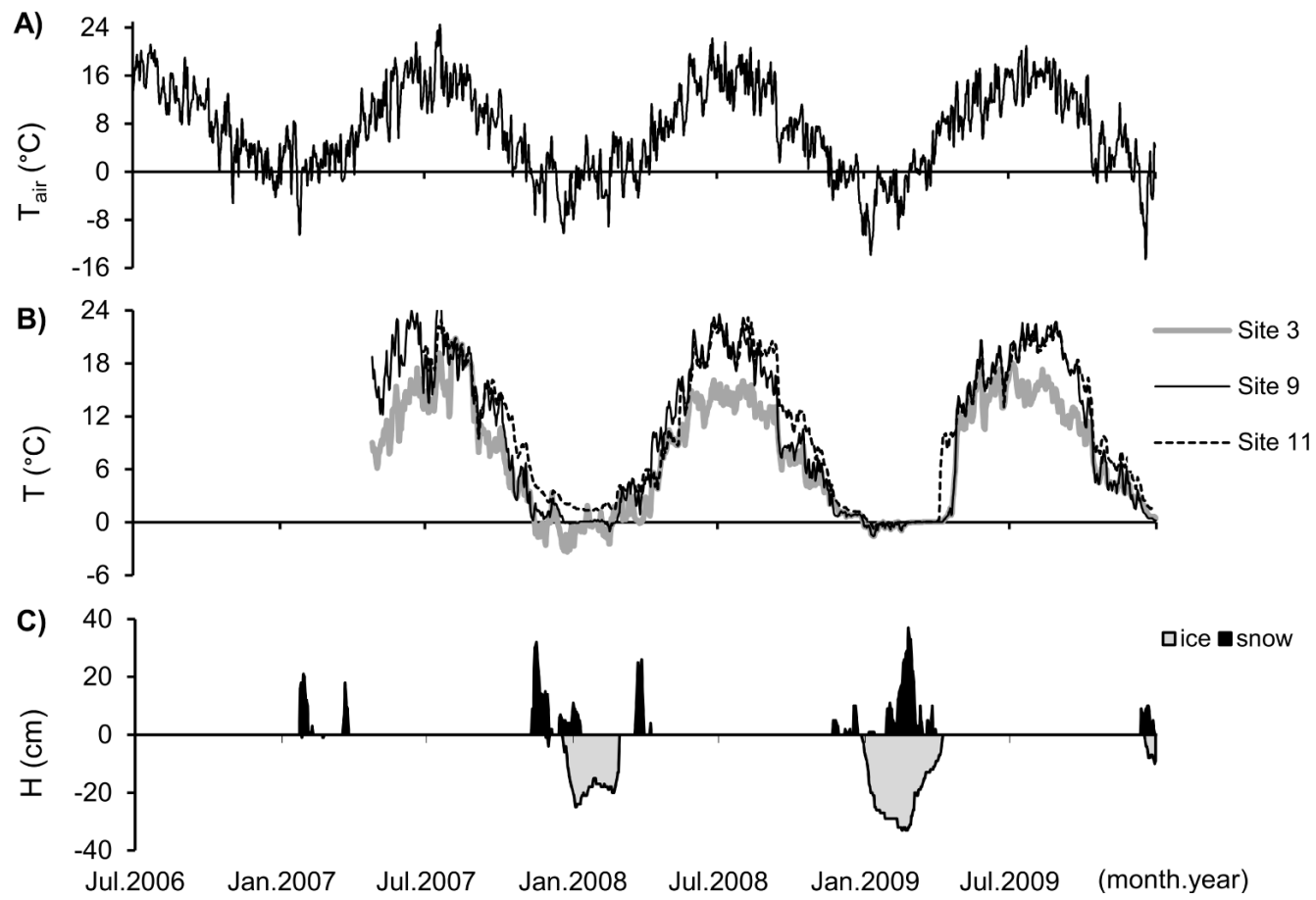

Figure 4

Daily mean values of selected climatic characteristics at Lipno Reservoir: (A) Air temperature; (B) temperature of substrate at sites 3, 9, and 11 during 2007-2009; C) height of snow cover and thickness of ice cover.

\section{Substrate}

The distribution of particle sizes in the upper layer of the substrate was similar at all sites except site 8 (Table I). While the substrate contained a large proportion of organic matter and fine clay and silt particles at most sites, coarse mineral components prevailed at site 8 . The chemical composition of the substrate was also similar at all sites except for sites 8 and 9 that had markedly higher contents of sulphur, phosphorus, aluminium and iron even when expressed per volume.

There was a negative logarithmic relationship between $\mathrm{pH}$ and the position of sites on the elevation gradient $\left(R^{2}=0.93\right)$. Minimum $\mathrm{pH}(4.8)$ was found at the driest site 1 and the highest values (above 6) at sites 10 to 12, situated in the lowest part of the gradient. In contrast to $\mathrm{pH}$, the soil redox potential did not correspond to the position on the elevation gradient so clearly; it ranged from -250 to $-330 \mathrm{mV}$ at all sites except site 1 , where it was higher (Table I).

\section{$>$ VEGETATION}

\section{Occurrence of macrophyte species}

Littoral vegetation was well developed in the bay. However, it extended only in the eulittoral zone while the infralittoral zone was not developed. The littoral vegetation was dominated by perennial emergent species; amphibious species and annual species of bare bottoms occurred either temporarily or as accompanying species (Table II).

Species composition and cover changed with location along the elevation gradient. The driest part of the transect (sites 1-5; flooded for less that 30\% of time) was occupied by perennial species of Phalaris arundinacea (terrestrial form), Phragmites australis, and Carex vesicaria that all had a high constancy and cover there (Table II, Figures 5 and 6). 


\section{Table I}

Physicochemical characteristics of the substrate at 12 sites along the elevation gradient in the eulittoral zone of Vresná bay. LOI - loss on ignition, Eh - redox potential adjusted to $\mathrm{pH}=7$. Outlying values are in bold.

\begin{tabular}{|c|c|c|c|c|c|c|c|c|c|c|c|c|c|}
\hline \multirow{2}{*}{$\begin{array}{l}\text { Site } \\
\text { No. }\end{array}$} & \multicolumn{3}{|c|}{ Fraction $(\%)$} & \multirow{2}{*}{$\begin{array}{l}\text { LOI } \\
(\%)\end{array}$} & \multirow{2}{*}{$\begin{array}{l}\text { Bulk density } \\
\left(\mathrm{g} \cdot \mathrm{cm}^{-3}\right)\end{array}$} & \multicolumn{6}{|c|}{ Elemental composition $\left(\mathrm{mg} \cdot \mathrm{cm}^{-3}\right)$} & \multirow{2}{*}{$\mathrm{pH}$} & \multirow{2}{*}{$\begin{array}{l}\text { Eh } \\
(\mathrm{mV})\end{array}$} \\
\hline & sand & silt & clay & & & $\mathrm{C}$ & $\mathrm{N}$ & $S$ & $P$ & $\mathrm{Fe}$ & Al & & \\
\hline 1 & 21 & 21 & 58 & 65 & 0.27 & 97 & 3.7 & 0.73 & 0.32 & 2.0 & 8.7 & 4.8 & -84 \\
\hline 2 & 7 & 36 & 57 & 66 & 25 & 89 & 4.3 & 0.78 & 0.35 & 2.1 & 7.5 & 5.3 & -324 \\
\hline 3 & 8 & 38 & 54 & 66 & & 86 & 4.3 & 0.73 & 0.31 & 2.1 & 5.1 & 5.6 & -278 \\
\hline 4 & 7 & 43 & 50 & 63 & 32 & 116 & 4.7 & 0.74 & 0.30 & 2.5 & 9.4 & 5.7 & -272 \\
\hline 5 & 22 & 33 & 45 & 78 & .20 & 88 & 3.2 & 0.57 & 0.22 & 1.0 & 4.5 & 6.0 & \begin{tabular}{|l}
-276 \\
\end{tabular} \\
\hline 6 & 7 & 46 & 47 & 62 & 0.20 & 69 & 3.0 & 0.45 & 0.23 & 1.7 & 4.3 & 5.7 & -286 \\
\hline 7 & 12 & 44 & 44 & 67 & .25 & 87 & 3.8 & 0.56 & 0.27 & 2.5 & 5.6 & 5.9 & -249 \\
\hline 8 & 35 & 30 & 35 & 19 & 0.79 & 92 & 4.6 & 0.95 & 0.47 & 15.8 & 26.9 & 6.0 & -314 \\
\hline 9 & 23 & 15 & 62 & 44 & 0.38 & 117 & 5.4 & 1.38 & 0.27 & \begin{tabular}{|l|}
3.7 \\
\end{tabular} & 6.2 & 6.3 & -329 \\
\hline 10 & 8 & 25 & 67 & 51 & 0.24 & 82 & 3.2 & 0.68 & 0.18 & 2.2 & 3.7 & 6.4 & -305 \\
\hline 11 & 19 & 37 & 44 & 78 & 0.21 & 96 & 3.5 & 0.71 & 0.20 & 1.7 & 3.0 & 6.2 & -306 \\
\hline 12 & 25 & 40 & 35 & 83 & 0.20 & 91 & 3.3 & 0.57 & 0.18 & 1.2 & 2.4 & 6.3 & -266 \\
\hline $\min$ & 7 & 15 & 35 & 19 & 0.20 & 69 & 3.0 & 0.45 & 0.18 & 1.0 & 2.4 & 4.8 & -329 \\
\hline median & 16 & 36 & 49 & 65 & 0.25 & 90 & 3.7 & 0.72 & 0.27 & 2.1 & 5.4 & 6.0 & -282 \\
\hline $\max$ & 35 & 46 & 67 & 83 & 0.79 & 117 & 5.4 & 1.38 & 0.47 & 15.8 & 26.9 & 6.4 & -84 \\
\hline
\end{tabular}

\section{Table II}

Ecological characteristics and measured constancy values of plant species occurring at 12 sites along the elevation gradient in the eulittoral zone of Vresná bay during three subsequent growing seasons (2007-2009). ELL - Ellenberg index for water regime (Ellenberg et al., 1992); L - life cycle ( $p$, perennial species; a, annual species); G - functional groups according to habitat preference (T, hydrophilic terrestrial; $E$, emergent; $A$, amphibious; F, free floating); $B$ - species of bare bottoms (+, yes; -, no).

\begin{tabular}{|c|c|c|c|c|c|c|c|c|c|c|c|c|c|c|c|c|}
\hline \multirow{3}{*}{ Species } & \multirow{3}{*}{ 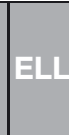 } & \multirow{3}{*}{ L } & \multirow{3}{*}{\multicolumn{2}{|c|}{ G): }} & \multicolumn{12}{|c|}{ Constancy (\%) } \\
\hline & & & & & \multicolumn{12}{|c|}{ Site No. } \\
\hline & & & & & 1 & 2 & 3 & 4 & 5 & 6 & 7 & 8 & 9 & 10 & 11 & 12 \\
\hline Alisma plantago-aquatica L. & 10 & $p$ & $A$ & - & & & 4 & 4 & 4 & 21 & 21 & 8 & 8 & & & \\
\hline Alopecurus aequalis Sobol. & 9 & $a$ & $A$ & + & & & & & 4 & 29 & 46 & 46 & 33 & 13 & 17 & 8 \\
\hline Bidens cernua L. & 9 & a & $\mathrm{T}$ & + & & & & 17 & 13 & 13 & 17 & 13 & 4 & 4 & & \\
\hline Carex vesicaria L. & 9 & $\mathrm{p}$ & E & - & 96 & 100 & 96 & & & 8 & 4 & & & & & \\
\hline Eleocharis acicularis (L.) R. et Sch. & 10 & $p$ & $A$ & + & & & & & 8 & 46 & 50 & 75 & 42 & 21 & 21 & \\
\hline Galium palustre L. & 9 & $\mathrm{p}$ & $\mathrm{T}$ & - & 50 & 21 & 17 & & & & & & & & & \\
\hline Glyceria fluitans (L.) R.Br. & 9 & $\mathrm{p}$ & $A$ & - & & & & & & 4 & 50 & 4 & 33 & & & \\
\hline Juncus articulatus L. & 8 & $\mathrm{p}$ & $E$ & - & & & & & & 8 & & & & & & \\
\hline Juncus bufonius L. & 7 & a & $\mathrm{E}$ & + & & & & & & 17 & 13 & 8 & & & & \\
\hline Juncus filiformis L. & 8 & $a$ & $\mathrm{E}$ & - & & & & & & 25 & 17 & & 8 & & & \\
\hline Lemna minor $\mathrm{L}$. & 11 & a & $\mathrm{F}$ & - & & & & & 4 & 4 & & & & & & \\
\hline Peplis portula L. & 7 & a & $\mathrm{E}$ & + & & & & & 4 & 8 & 8 & 8 & & 4 & & \\
\hline Phalaris arundinacea (L.) Roth. LIM form & 8 & $\mathrm{p}$ & $E$ & - & & & & & & 92 & 100 & 92 & 100 & 17 & 25 & \\
\hline Phalaris arundinacea (L.) Roth. TER form & 8 & $\mathrm{p}$ & E & - & 100 & 100 & 100 & 13 & 46 & & & & & & & \\
\hline Phragmites australis (Cav.) Steud. & 10 & $p$ & $\mathrm{E}$ & - & & 33 & 83 & 88 & 88 & 96 & 54 & 4 & & & & \\
\hline Ranunculus flammula L. & 9 & $p$ & $\mathrm{E}$ & - & & & & & 4 & 54 & 54 & 4 & & 4 & & \\
\hline Sparganium erectum L. & 11 & $p$ & $\mathrm{E}$ & - & & & & & & 13 & 58 & 50 & 25 & & & \\
\hline Typha latifolia L. & 10 & $p$ & $E$ & - & & & & & & 8 & 58 & & & & & \\
\hline Utricularia australis $\mathrm{R}$. Br. & 12 & $a$ & $F$ & - & & & & 4 & & & & & & & & \\
\hline
\end{tabular}



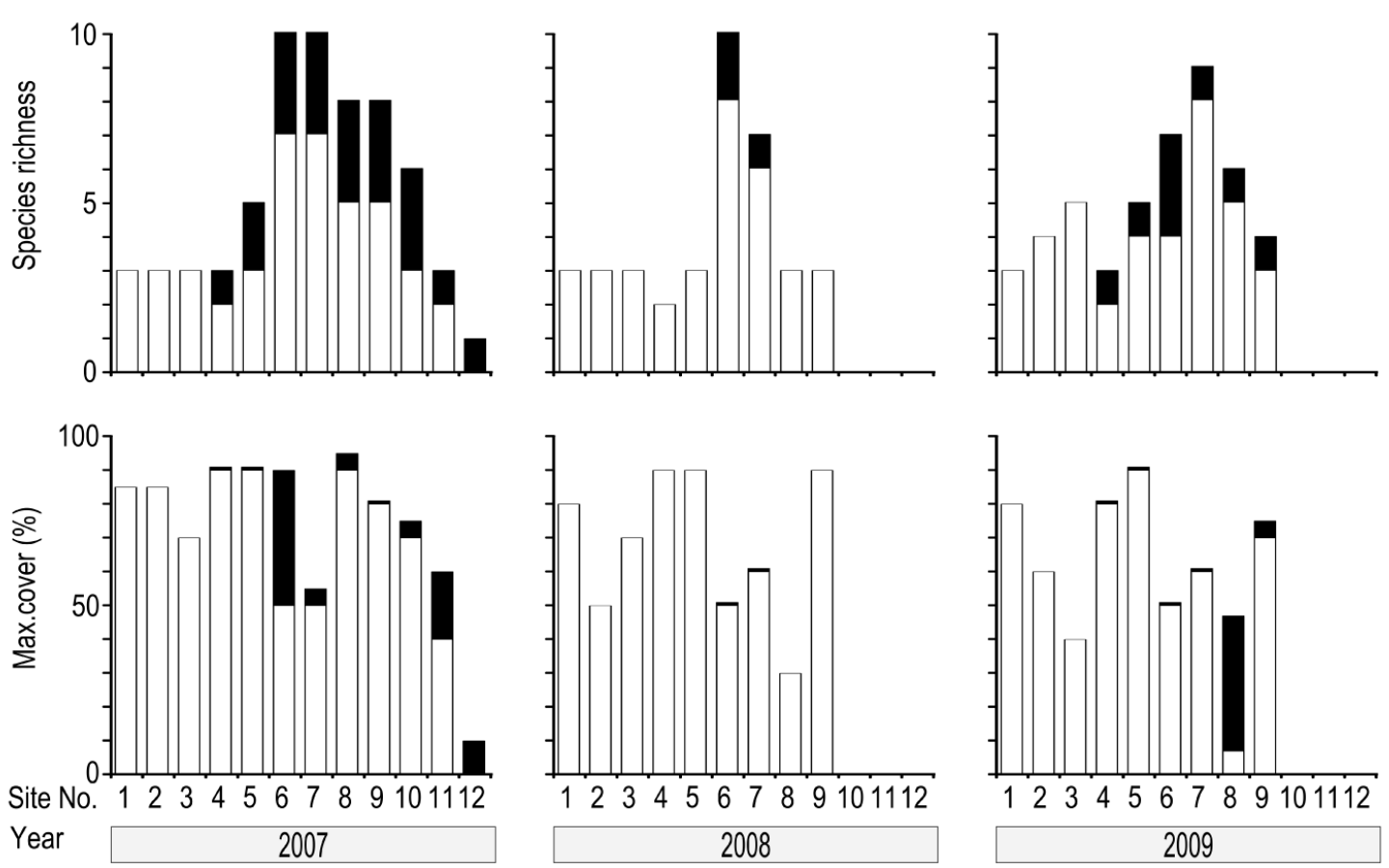

\section{Figure 5}

The number and maximum cover of annual and perennial species at the study sites along the elevation gradient during 2007-2009. Black colour - annual species; white colour - perennial species.

In contrast, the middle part of the transect (sites 6-9; flooded for 30-50\% of time) was characterized by a lower total cover but a higher species diversity (Table II, Figures 5-6). The vegetation was composed of both perennial species (limosal form of Phalaris arundinacea; Eleocharis acicularis, Sparganium erectum, Alisma plantago-aquatica, Glyceria fluitans, and Typha latifolia and annual species (Alopecurus aequalis, Juncus bufonius, Juncus filiformis, and Peplis portula). The presence of particular species differed between years. Only Phalaris arundinacea showed a high constancy and cover values and was present on sites 6, 7 and 9 throughout the whole observation period.

The lowest part of the elevation gradient (sites 10-12; flooded for $50-80 \%$ of time) was covered with vegetation only in 2007, when all three sites hosted Alopecurus aequalis in spring. In addition, there was a fairly well developed cover of Eleocharis acicularis and a low cover of Phalaris arundinacea on sites 10 and 11 in spring and autumn (cf. Table I and Figure 6), i.e. during periods of high water transparency (Figure 3C).

\section{Performance of dominant species}

Phalaris arundinacea was the most common species in the littoral vegetation. It was present on most of the sites along the elevation gradient but it created two different growth forms, terrestrial and limosal. The terrestrial form was characterized by freely stoloniferous shoots (growing from rhizomes) whereas the limosal form produced distinct clumps of shoots (growing from parent shoots declined to the soil surface and rooted). The terrestrial form was found mainly in the least flooded sites 1-3, while the limosal form was present in the frequentlyflooded sites 7-10.

The allometric relationships of shoots, i.e. the relation between shoot height and dry weight, indicate the differential performance of a species and its life forms in subsequent years (Figures 7A, B; Table III). The shoots of limosal form of $P$. arundinacea started growing earlier in the spring, were generally taller, and died back earlier in the autumn than those of the 


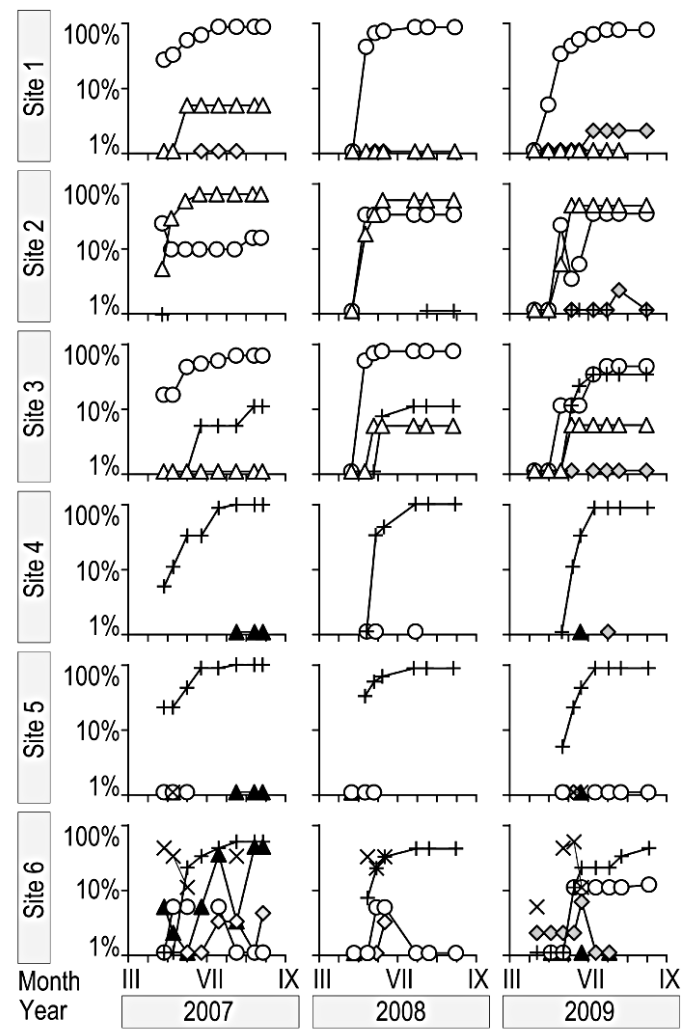

$\Delta$ annual species $\diamond$ perennial species $\bigcirc$ Phalaris arundinacea
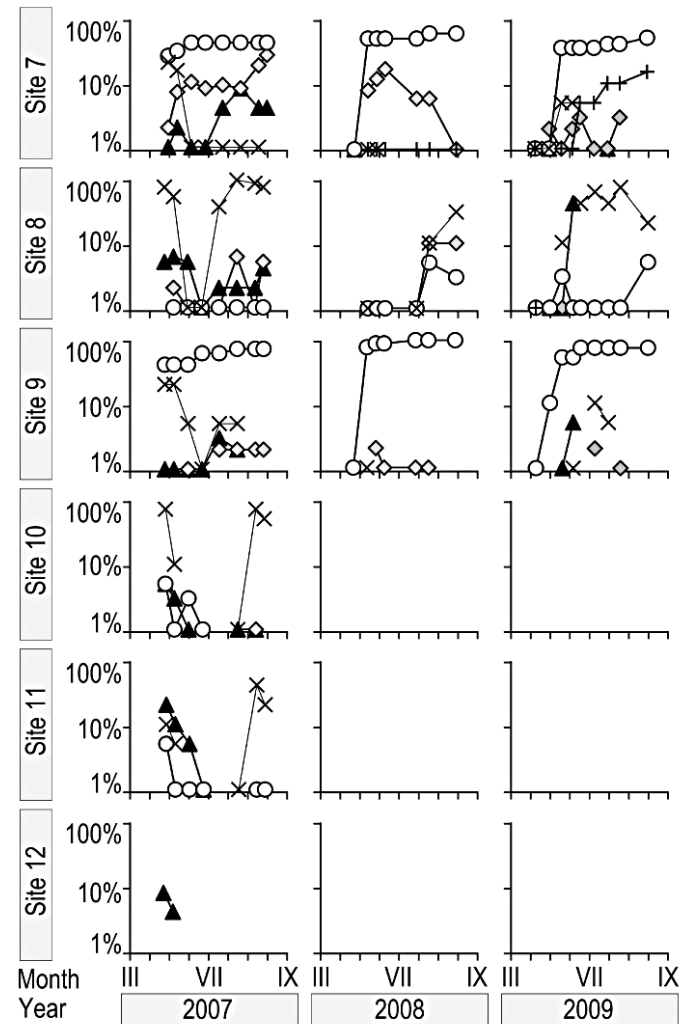

+ Phragmites australis $\Delta$ Carex vesicaria $\times$ Eleocharis acicularis

Figure 6

Seasonal changes in the cover of dominant plant species at different sites along the elevation gradient during 2007-2009.

terrestrial form. In 2007 and 2008, environmental conditions favoured the performance of the limosal form of $P$. arundinacea, which then formed shoots up to $1.6 \mathrm{~m}$ in length. Conversely, the growth of the terrestrial form of $P$. arundinacea was limited most in 2007, as indicated by its maximum shoot length of only about $1 \mathrm{~m}$ (Figures 7A, B) and absence of flowering. Both shoot length and dry weight significantly differed between the terrestrial and limosal growth forms of $P$. arundinacea. The growth significantly differed between subsequent years for shoot dry weight, but not for length (Table III).

Similarly as the terrestrial form of $P$. arundinacea, $P$. australis performed best in 2009 , forming shoots up to $3 \mathrm{~m}$ in length and $30 \mathrm{~g}$ in dry weight (cf. Figures 7A, C). The inter-annual difference was significant for shoot dry weight, but not for shoot length (Table III). The shoot dry weight was significantly greater in the two wetter years of 2008 and 2009 than in the dry year of 2007.

\section{Relationship between environmental characteristics and vegetation}

Among the environmental variables tested, the only significant variables were the presence of the terrestrial ecophase and total cover of vegetation $(F=58.4 ; p=0.002)$. These two variables explained $35 \%$ of the variance, while the rest of the variables explained $5 \%$ more of the variance.

The RDA ordination diagram (Figure 8) clearly demonstrates the characteristic occurrence of only a few species on sites with prevailing terrestrial ecophase (Carex vesicaria, Galium palustre and the terrestrial form of Phalaris arundinacea). All the other species (Alisma 

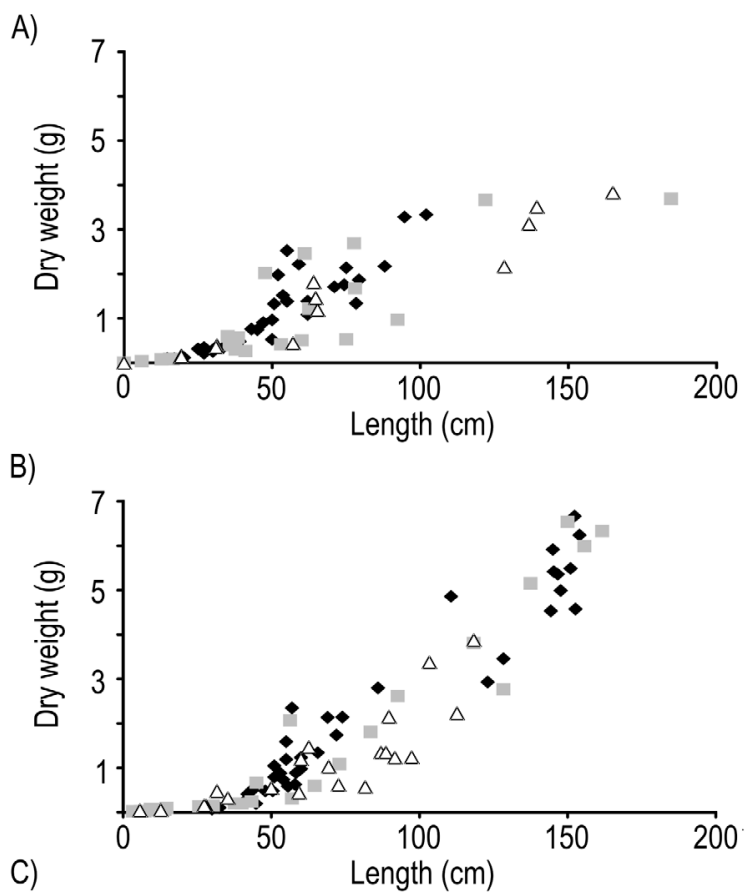

\section{Figure 7}

Allometric relationships between length and dry weight of shoots of $(A)$ terrestrial form of Phalaris arundinacea, (B) limosal form of P. arundiceae, and (C) Phragmites australis during 2007-2009.

\section{Table III}

Results of statistical analysis of allometric relationships in Phalaris arundinacea and Phragmites australis (GLM for Poisson distribution, see http://www.statsoft.com/textbook/generalized-linear-models/). Years - growing seasons in years 2007, 2008, 2009; Forms - limosal and terestrial form of Phalaris arundinacea; significant relationships are in bold.

\begin{tabular}{|c|c|c|c|c|c|c|c|c|c|c|}
\hline \multirow{3}{*}{ Variable } & \multicolumn{5}{|c|}{ Phalaris arundinacea } & \multicolumn{5}{|c|}{ Phragmites australis } \\
\hline & \multirow{2}{*}{ df } & \multicolumn{2}{|c|}{ shoot length } & \multicolumn{2}{|c|}{ dry weight } & \multirow{2}{*}{$d f$} & \multicolumn{2}{|c|}{ shoot length } & \multicolumn{2}{|c|}{ dry weight } \\
\hline & & $F$ & $p$ & $F$ & $p$ & & $F$ & $p$ & $F$ & $p$ \\
\hline Years & 2 & 0.11 & 0.90 & 3.11 & 0.047 & 2 & 0.96 & 0.39 & 3.14 & 0.049 \\
\hline Forms & 1 & 15.58 & 0.000 & 17.88 & 0.000 & - & - & - & - & - \\
\hline Forms $\times$ Years & 2 & 2.01 & 0.14 & 1.79 & 0.17 & - & - & - & - & - \\
\hline
\end{tabular}

plantago-aquatica, Alopecurus aequalis, Bidens cernua, Eleocharis acicularis, Glyceria fluitans, Juncus articulatus, Juncus bufonius, Juncus filiformis, Peplis portula, Phragmites australis, the limosal form of Phalaris arundinacea, Ranunculus flammula, Sparganium erectum and Typha latifolia) were typically associated with the limosal ecophase. No plant species were typically associated with the littoral ecophase,

The total vegetation cover was not clearly related to one particular ecophase. This was due to the fact that high cover was found not only in stands dominated by Carex vesicaria and 


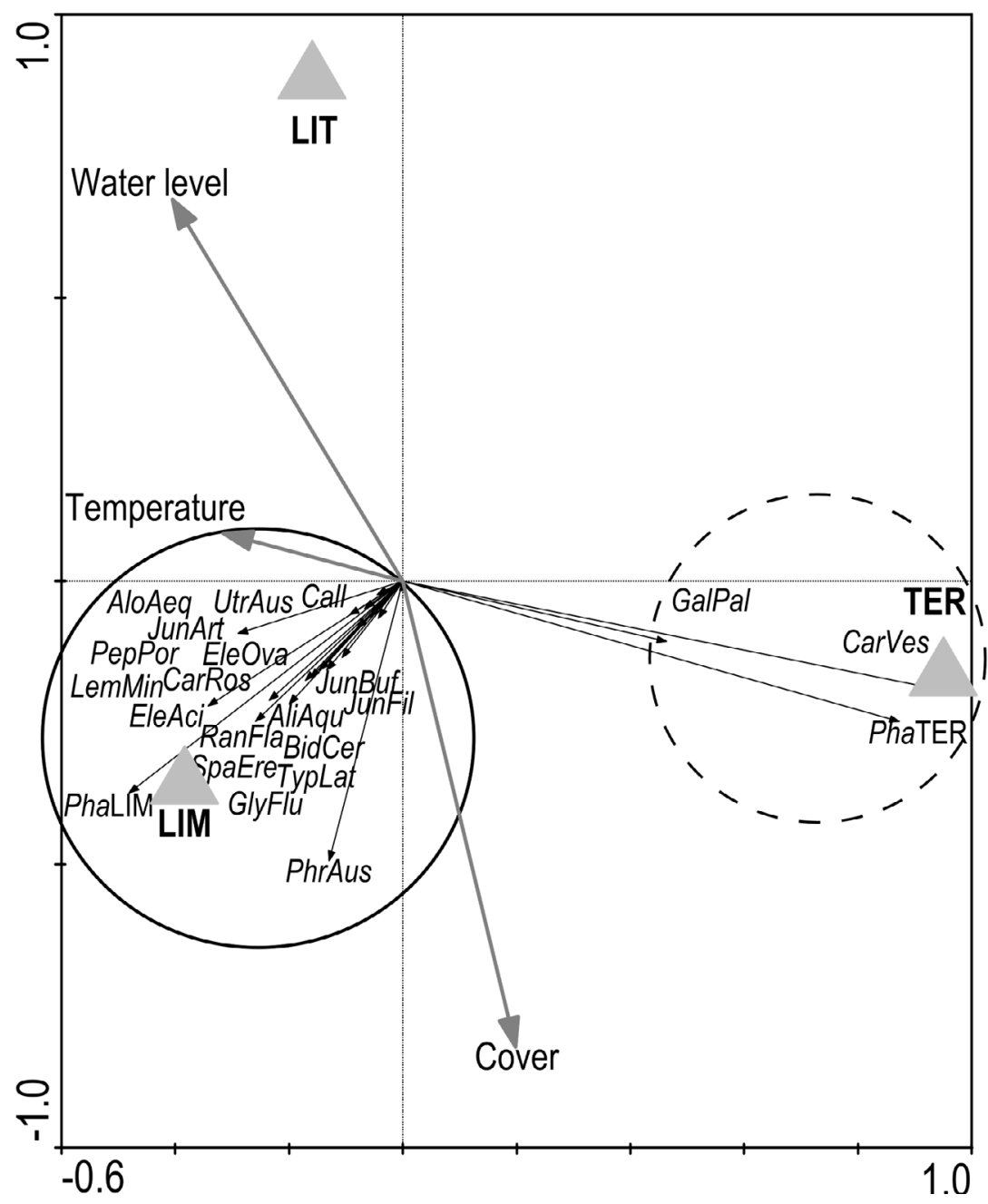

\section{Figure 8}

The RDA ordination diagram showing the effects of the significant variables (terrestrial ecophase and total vegetation cover). TER - terrestrial ecophase, LIM - limosal ecophase, LIT - littoral ecophase, Cover - total cover (\%), temperature $\left({ }^{\circ} \mathrm{C}\right)$ on the bottom, Water level (m); species: AliAqu - Alisma plantagoaquatica; AloAeq - Alopecurus aequalis; BidCer - Bidens cernua; CarVes - Carex vesicaria; EleAci Eleocharis acicularis; GalPal - Galium palustre; GlyFlu - Glyceria fluitans; JunArt - Juncus articulatus; JunBuf - Juncus bufonius; JunFil - Juncus filiformis; PepPor - Peplis portula; PhaLIM - Phalaris arundinacea in limosal ecophase; PhaTER - Phalaris arundinacea in terestrial ecophase. PhrAus - Phragmites australis. RanFla - Ranunculus flammula. SpaEre - Sparganium erectum; TypLat - Typha latifolia. Lines denote the boundaries of occurrence of species: Dashed line - species occurrence in the area with terrestrial ecophase; full line - species occurrence in the area with limosal ecophase.

the terrestrial form of Phalaris arundinacea, which occurred mostly in the terrestrial ecophase, but also in stands of Phragmites australis that occurred in the limosal ecophase.

\section{DISCUSSION}

\section{> EFFECTS OF KEY ENVIRONMENTAL FACTORS ON THE VEGETATION PERFORMANCE}

The results document the spatial, seasonal and inter-annual variation of environmental factors that are likely to affect the vegetation performance. It is unlikely that either the air or soil 
temperatures during the vegetation period would markedly affect the performance of the vegetation as no extreme events were detected. On the other hand, the plant species distribution might have been affected by winter conditions, encompassing soil temperature combined with the presence or absence of ice or snow. Freezing of unflooded bottom is probably one of the factors responsible for the absence of submerged macrophytes, which can survive frost only in the form of seeds and turions (Hutchinson 1975). Emergent macrophytes, adapted to seasonal climate by shoot die-back and rhizome dormancy similarly as terrestrial perrenials, apparently coped with frost well.

Although the chemical characteristics were similar all along the elevation gradient, their effects on the vegetation apparently differed in the three eulittoral sub-zones as they specifically combined with different flooding regimes. The zonation likely resulted from the combined effects of three major factors, all related to the seasonal dynamics of the water level: 1 . anaerobic character of the bottom; 2 . low nutrient availability; and 3 . limits to generative dispersal.

\section{> ANAEROBIC SUBSTRATE}

The redox potential results (Table I) indicate that, at the time of measurement, there were strongly reducing conditions in the water-saturated substrate at all sites except site 1 . The products of anaerobic microbial metabolism occurring in the water-saturated bottom (e.g. organic acids, hydrogen sulphide) are toxic for the young parts of roots and rhizomes (Armstrong and Armstrong, 2001).

Continuous measurements of redox potentials in previous studies indicate that the redox potential is quite stable at a particular site so long as the soil is saturated with water (Richardson and Vepraskas, 2000). Drying brings about a sharp increase in redox potential (Č́źǩková et al., 2001) and a rapid loss of toxic anaerobic substances (Čížková et al., 1999). The lack of oxygen and the anaerobic toxins will therefore affect the vegetation differently in the three sub-zones because their persistence is related to the duration of flooding. The strongest effects would be expected in the lowest zone where the water table sinks below the soil surface only exceptionally once in several years.

Wetlands plant species are adapted to soil anaerobiosis by the internal ventilation of their below-ground parts (roots and rhizomes); the ventilation processes transport enough oxygen to the cells of the below-ground parts and to the substrate around their tips (Armstrong et al., 1994). Oxygen present in the oxidised layer protects the tips from the toxic effects of anaerobic microbial products found in water-saturated soils (Gambrell and Patrick, 1978; Ponnamperuma, 1984). Yet, the supply of oxygen to plant below-ground tissues can be insufficient under some circumstances. Root aeration by diffusion (Armstrong, 1979; Armstrong et al., 1991a, b) is significantly reduced with increasing height of the water column, because of the extended diffusion path. In addition, extremely reducing environments markedly increase the need for an oxygen supply (Brix and Sorrell, 1996).

The density of perennial emergent plants in the three sub-zones indicates that the plants cope well with the conditions of the anaerobic substrate in the upper eulittoral, with only partial success in the middle eulittoral, and fail in the lower eulittoral over the long term.

\section{> NUTRIENT AVAILABILITY}

The chemical characteristics of the bottom which were largely similar along the depth gradient (Table I) indicated a very low nutrient availability for plants at the site. There are three additional arguments to support this statement. First, the preliminary fractionation analyses of the soil indicated that a much larger part of the phosphate was bound to compounds with aluminium compared to iron. Aluminium does not change its oxidation status in response to oxygen depletion; therefore, aluminium-bound phosphate in this fraction is not solubilised upon soil flooding as is iron-bound phosphate. Second, the large content of organic matter in the substrate all along the depth gradient indicates that a considerable proportion of nutrients 
may not be quickly recycled because they are bound in newly-formed peat. Third, the aboveground biomass production is considerably lower compared to similar communities in other littoral habitats of the region. For instance, the seasonal maximum above-ground biomass of the stand of Phalaris arundinacea and Carex spp. on the uppermost part of the transect achieved $0.10-0.12 \mathrm{~kg} \cdot \mathrm{m}^{-2}$ (Krolová et al., 2011) compared to $0.71-1.3 \mathrm{~kg} \cdot \mathrm{m}^{-2}$ in habitats of Mokré Louky near to the town of Třeboň; Czech Republic (Káplová et al., 2010). Phragmites australis achieved an above-ground biomass of $0.27 \mathrm{~kg} \cdot \mathrm{m}^{-2}$ on the transect (Krolová et al., 2011), while values of about $1-2 \mathrm{~kg} \cdot \mathrm{m}^{-2}$ are reported from the littorals of South Bohemian fishponds (Dykyjová and Květ, 1978; Č́žková et al., 2001).

The above observations indicate that plant growth may be limited by nutrients. In stands largely unaffected by water table fluctuations and other causes of disturbance, nutrient availability determines the species composition and production of the stands. This is demonstrated for example by Hroudová et al. (1988) for the littoral zone of a large man-made lake. In studies of habitats with fluctuating water levels, the effects of nutrient availability must be additionally considered in connection with effects of disturbance and other damage, caused to the biomass produced. The biomass at a particular site will result from the interaction of two mutually opposing processes: it is increased by production (including seasonal production and regeneration after damage) and diminished by losses caused by natural die-back, induced damage (e.g. the death of root tips and terminal buds due to toxicity in the substrate) and mechanical disturbance. The losses of plant parts resulting from damage are compensated for in the process of regeneration. Regeneration following damage is supported by a sufficient supply of nutrients and metabolic energy. Vice versa, this process can be limited on sites with a lack of mineral nutrients. Hence, nutrient limitation will have stronger effects in the middle eulittoral, where the vegetation is more affected by anaerobic stress in the root zone, than in the upper littoral. The limiting effect of nutrients thus may partly account for the low cover in the middle eulittoral.

\section{Limits to generative dispersal}

The variable occurrence of annual species in different sub-zones and different years of the study suggest the importance of suitable conditions for sexual reproduction and seedling establishment. Available studies of seedling establishment of emergent macrophytes indicate that wet bare bottoms represent the best conditions, combining wet, but not flooded substrate, and light indicating space free of competition (Hejný and Husák, 1978; Weisner and Ekstam, 1993; Ekstam et al., 1999). Accordingly, the middle eulitoral with only a partial cover of perennial emergent macrophytes offers the best space for seedling establishment.

\section{> SEQUENCE OF ECOPHASES DETERMINES THE VEGETATION ZONATION}

The results of our study indicate that three sub-zones can be distinguished within the eulittoral zone: upper, middle and lower. In addition to the typical vegetation characteristics, the subzones are also characterised by the extent and dynamics of flooding, which can be described using the concept of a sequence of ecophases sensu Hejný and Segal (1998). As indicated by the results of the RDA analysis (Figure 8 ), the character of vegetation is on the whole consistent with the ecophase that is prevailing in that particular sub-zone during the summer. Closer inspection reveals an additional effect from the ecophase that was prevailing in the preceding autumn. The vegetation character in a particular year is thus associated with the sequence of prevalent ecophases that occur in the autumn of the preceding year and the spring and summer of the current year. Similar effect of previous year on successive year spring biomass was published for submerged and floating leaved macrophytes by Janauer and Wychera (2000).

In the upper eulittoral (sites 1 to 5 in this study) the typical sequence of ecophases consists of the terrestrial ecophase in autumn followed by the limosal ecophase in spring and the terrestrial to limosal ecophase in summer (Figure 9). The sub-zone supports a stable community 


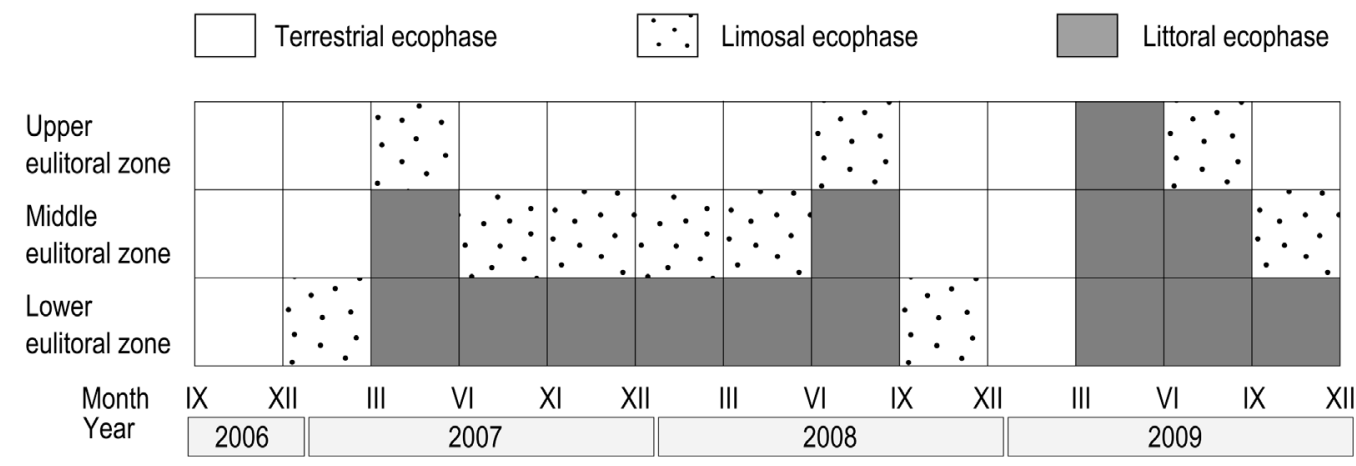

Figure 9

Sequence of prevailing ecophases in eulittoral zonation.

formed by a small number of perennial plant species with high cover. Historical records indicate that a similar type of Carex-dominated herbaceous community on a waterlogged soil occurred in the area prior to the reservoir being filled (Minár, 1964). The stable species composition and high cover indicate that the community copes well with seasonal fluctuations of the water table. Furthermore, the persistence of standing dead plant material also implies that the live plant parts are not mechanically damaged by water movement. Under such conditions, plants are able to invest in long-term structures such as large systems of roots and rhizomes, which can serve a number of functions. Extensive root systems serve not only for the acquisition of resources (nutrients and water) from the soil but also bring enough oxygen to their own cells and to the substrate around their tips. Rhizomes contribute to the ventilation of the whole below-ground system, store reserves of carbohydrates and nutrients for fast spring re-growth, and serve for further vegetative spreading. Interspecific competition below the ground is therefore a most likely factor shaping the community.

In the middle eulittoral (sites 6-9), the typical sequence of ecophases consists of the limosal ecophase in autumn, and the littoral ecophase in the subsequent spring followed by the limosal ecophase in summer (Figure 9). The vegetation is characterized by a relatively high richness of emergent and amphibious species, which are, nevertheless, present with fairly low cover values (cf. Figure 6). The stress effects of the anaerobic bottom are more pronounced in the middle eulittoral than in the upper eulittoral and may account for the low vegetation cover. The emergent macrophytes species present are characterised by shallow root systems, thus minimising their contact with the reducing conditions (i.e. Phalaris arundinacea and most annual species). The die-back resulting from substrate toxicity is partly balanced by vegetative regeneration. Temporary populations of amphibious species and species of bare bottoms (Hejný and Husák, 1978; Šumberová et al., 2006) develop in the open space between clumps of perennial plants when the water level drops to the bottom surface. This results in a community with high dynamics.

The lower eulittoral with a prevailing littoral ecophase (sites 10-12) (Figure 9) is devoid of permanent vegetation. The reducing conditions in the bottom substrate, combined with the partial flooding of shoots, probably account for the absence of emergent macrophytes. Nevertheless, if the lower eulittoral is not flooded during autumn (Figure 9), favourable conditions for the temporary occurrence of species of bare bottoms are created there. Submerged and floating-leaved macrophytes were absent in the lower eulittoral zone in this study and are generally poorly represented throughout the whole littoral of Lipno Reservoir (Krolová et al., 2012). Water transparency is unlikely to limit the occurrence of submerged macrophytes because it was 'very good to acceptable' in the shallow water near the shore throughout the study period (Figure 3C). Erosion promoted by wave action, water level fluctuation and bottom freezing and thawing during winter (Björk et al., 1972; Coops and Hosper, 2002; Vilmundardóttir et al., 2010; Krolová et al., 2012) is also an unlikely cause, as its signs have not been observed on the transect. Rather, the regular drying of the bay bottom during winter appears a likely cause (cf. the effects of winter time temperature discussed above). 


\section{> ECOLOGICAL IMPORTANCE OF MACROPHYTES IN THE EULITTORAL ZONE OF RESERVOIRS AND MANAGEMENT OPTIONS TO SUPPORT MACROPHYTE GROWTH}

The results of our study indicate, like many previous studies (e.g. Hill et al., 1998; Keddy and Reznicek, 1986; Wantzen et al., 2008), that the presence and growth of macrophytes in the littoral zone of regulated lakes and reservoirs are strongly influenced by water level fluctuations. However, we have also demonstrated that the littoral macrophyte assemblage is markedly affected not only by the range, but also by the seasonal pattern of water level fluctuations. While the eulittoral vegetation copes well with high water levels in spring and early summer, it benefits from gradual decrease of water table during the second half of the summer and autumn. After the water level declines in summer and autumn, stands of emergent macrophytes in the eulittoral can regenerate vegetatively and open sites can be inhabited by annual species of bare bottoms from seeds under non-flooding conditions. These plants are then able of overwintering irrespectively of dry or wet soil conditions and can grow and reproduce under flooding conditions during the next spring and first part of summer. On the contrary, in parts of the eulittoral that are flooded during the whole growing season or at least during its second part, these macrophyte species gradually decline (due to their apparent inability to accommodate to multiple stresses including nutrient scarcity, insufficient oxygen transport to belowground plant parts through the high water column, toxicity of anaerobic conditions in flooded soils, unfavourable conditions for seed germination) and the area becomes largely uninhabited in the next season.

The knowledge of this principle can be employed in reservoir management for the control of macrophyte development in the littoral zone. The Water Framework Directive requires occurrence of littoral macrophytes on all suitable sites of any water body, which reflects the understanding of high ecological importance of macrophyte stands in the aquatic ecosystem, for example in nutrient cycling (Gasith and Hoyer, 1998), protection of shores against erosion (Welch et al., 2003; McComas, 2003), zooplankton sheltering against predation, and healthy fish reproduction (Gasith and Hoyer, 1998; Scheffer, 1999; Welch et al., 2003). Even a small extent littoral communities in deep water bodies can have substantial effects on biotic interactions and community structure in the aquatic ecosystem (Gasith and Hoyer, 1998). The presence of macrophyte stands is of a key importance for the aquatic ecosystem especially during the spring and summer period when they provide spawning area for many fishes and later food base and shelter for the fingerlings. Natural lakes of the temperate zone typically feature maximum water levels and maximum shore flooding during the spring and early summer (Keddy and Reznicek, 1986; Wantzen et al., 2008). Apparently, the timing of fish spawning and development of their offsprings is an ecological adaptation to this natural pattern of hydrological and climatic conditions (Shoup and Wahl, 2009). This provides also rationales for orientation of management of reservoir water pool in this direction.

Currently, the operation of Lipno Reservoir, as well as operations of many other storage reservoirs designed for hydropower, flood control, flow maintenance, and/or water supply in Czechia and other European countries do not intentionally consider ecological effects of water level fluctuations. The water level in Lipno Reservoir has a maximum in spring months due to regularly high runoff from the catchment in this period and due to an intentionally lowered water level in the November-March period with the purpose to increase the flood control capacity before the snow melt; otherwise the reservoir operation follows the needs for water supply and flow augmentation downstream from the dam. Water level changes during the growing season are hence without a regular pattern: a high water level almost without fluctuations occurs in years of high flow conditions but up to 3-m drops in water level are common in years of subnormal flow. This irregular water level regime has negative consequences for aquatic plants. While the regular water level drawdowns in winter eliminate growth of submerged macrophytes and creation of infralittoral zone in this reservoir, the prevailing high water level conditions lasting over the growing season in some years impair the growing potential for emergent and amphibious species in the middle and lower eulittoral. 
The results of this study suggest that reservoir operation practice in Lipno Reservoir can be adjusted to support macrophytes in the eulittoral zone, hence improving its ecological potential. This ecological water level regulation is based on the principle of keeping the water level high during the spring and early summer period (i.e. above the elevation of ca 724.3 masl from April to July) followed by a water level decrease in the late summer and autumn by a certain height to maintain suitable areas of bottom unflooded for the establishment and annual renewal of eulittoral macrophyte stands (for example, the decrease of water level by $0.7 \mathrm{~m}$ to 723.6 masl from August to October would expose to drying ca $2.4 \mathrm{~km}^{2}$ of bottom, which is almost $6 \%$ of the reservoir area). No other demands to control water level below this lower level in the second regulation period and later are required and reservoir operation may follow all other purposes until the next spring.

The ecological regulation partly restricts the flexibility of reservoir operation, however, in Lipno Reservoir as well as in many other storage reservoirs that operate on a one-year filling and emptying cycle, it does not contradict the major reservoir purposes that lies in the storage of maximum volume of water in the spring period of maximum runoff for flow augmentation and water supply in the following low flow periods. The controlled lowering of water level can potentially lead to a less profitable hydropower production, however, even this might not be very important. In Lipno Reservoir, the decrease of hydropower production efficiency would be small; for example, a change from the real (2006-2009) to the suggested ecological water level operation would result in a 3-cm decrease of the mean water level, which corresponds to a negligible $0.02 \%$ loss of water pressure head which is directly proportional to the produced hydropower.

On the other hand, the ecological regulation of water level for the support of eulittoral macrophyte stands can result, in addition to the improved ecological potential, in several benefits, mainly (i) increased stability of vegetated shores against erosion without investing in extra remediation actions, (ii) support of natural reproduction of fishes, especially of carnivorous species like pike and pike perch that are favourite game fishes in Lipno Reservoir, and (iii) potential improvement of water quality that can arise from the cascading effect of higher abundance of carnivorous fishes in the food web resulting in more intense zooplankton grazing of phytoplankton and from the ability of littoral stands to bind nutrients and make them unavailable for phytoplankton growth.

\section{CONCLUSIONS}

1. Three sub-zones were distinguished within the eulittoral zone at the Vřesná bay of Lipno Reservoir: (i) the upper eulittoral with a stable plant community formed by a small number of perennial plant species at high cover in conditions of occasional flooding (less that $30 \%$ of the time), (ii) the middle eulittoral with a relatively high richness of emergent and amphibious species present at fairly low cover values in the zone of moderate flooding (30-50\% of the time), and (iii) the lower eulittoral devoid of permanent vegetation in the zone of predominant flooding (50-80\% of the time).

2. Seasonal variability of flooding conditions constituted the main factor influencing the vegetation in the eulittoral zone. Competition for below-ground resources was likely to shape of the community of the upper eulittoral. Substrate toxicity upon flooding partly restricted the growth of emergent plants in the middle eulittoral and accounted for its total absence in the lower eulittoral of the site studied. The occurrence of an unflooded, bare bottom in summer and autumn was essential for the regeneration of emergent plants and new establishment of seedlings in these two sub-zones.

3. The results of this study demonstrate that macrophyte growth in the middle and lower eulittoral is strongly dependent on the duration and timing of flooding. A relatively modest regulation of reservoir water level during the growing season that does not contradict major reservoir purposes can support the formation of eulittoral macrophyte stands and their ecological functioning in the aquatic ecosystem. The promotion of vegetation in the eulittoral zone can help reservoir managers to improve the ecological potential in the sense 
of the EU Water Framework Directive, especially in the case of reservoirs where the morphology of shores can allow the macrophyte growth.

\section{ACKNOWLEDGEMENTS}

This research was funded by research programmes AV0Z60170517 of the Academy of Sciences of the Czech Republic and MSM6007665801 of the Ministry of Education of the Czech Republic, with additional support from the project No. 206/09/1764 of the Grant Agency of the Czech Republic, the EU FP7 project No. 244121 REFRESH, and project No. 7E11059 of the Ministry of Education of the Czech Republic. We thank Jiři Dušek for help with the measurement of redox potential $\left(E_{\mathrm{H}}\right)$ and Stephen Ridgill for language corrections.

\section{REFERENCES}

Armstrong W., 1979. Aeration in higher plants. In: Woolhouse H.W. (ed.), Advances in Botanical Research, Academic Press, London, Vol. 7, 225-332.

Armstrong J. and Armstrong W., 2001. An overview of the effects of phytotoxins on Phragmites australis in relation to die-back. Aquat. Bot., 69, 251-268.

Armstrong W., Beckett P., Justin S.H.F.W. and Lythe S., 1991a. Modelling and other aspects of root aeration by diffusion. In: Jackson M.B., Davies D.D. and Lambers H. (eds.), Plant Life under Oxygen deprivation, APB Academic Publishing, The Hague, 267-282.

Armstrong W., Justin S.H.F.W., Beckett P.M. and Lythe S., 1991b. Root adaptation to soil waterlogging. Aquat. Bot., 39, 57-73.

Armstrong W., Brändle R. and Jackson M.B., 1994. Mechanisms of flood tolerance in plants. Acta Bot. Neerl., 43, 307-358.

Baxter R.M., 1977. Environmental effects of dams and impoundments. Annu. Rev. Ecol. Syst., 8, 255-283.

Björk S., Bengtsson L., Berggren H., Cronberg G., Digerfeldt G., Fleischer S., Gelin C., Lindmark G., Malmer N., Plejmark F., Ripl W. and Swanberg P.O., 1972. Ecosystem studies in connection with restoration of lakes. Verhandlungen des Internationalen Verein Limnologie, 18, 379-387.

Blindow I., 1992. Long and short-term dynamics of submerged macrophytes in two shallow eutrophic lakes. Freshwater Biol., 28, 15-27.

Bochove E., Beauchemin S. and Thériault G., 2002. Continuous multiple measurement of soil redox potential using platinum microelectrodes. Soil Sci. Soc. Am. J., 66, 1813-1820.

Brady N.C. and Weil R.R., 2002. The Nature and Properties of Soils, Prentice Hall, Upper Saddle River, New Jersey, 960 p.

Brix H. and Sorrell B.K., 1996. Oxygen stress in wetland plants: comparison of de-oxygenated and reducing root environments. Funct. Ecol., 10, 521-526.

Carpenter S.R. and Lodge D.M., 1986. Effects of submersed macrophytes on ecosystem processes. Aquat. Bot., 26, 341-370.

Č́žková H., Brix H., Kopecký J. and Lukavská J., 1999. Organic acids in the sediments of wetlands dominated by Phragmites australis: evidence of phytotoxic concentrations. Aquat. Bot., 64, 303-315.

Čížková H., Pechar L., Husák Š., Květ J., Bauer V., Radová J. and Edwards K., 2001. Chemical characteristics of soils and pore waters of three wetland sites dominated by Phragmites australis: relation to vegetation composition and reed performance. Aquat. Bot., 69, 235-249.

Coops H. and Hosper S.H., 2002. Water-level management as a tool for the restoration of shallow lakes in the Netherlands. Lake Reserv. Manage., 18, 293-298.

Directive 2000/60/EC of the European Parliament and of the Council of 23 October 2000 establishing a framework for Community action in the field of water policy. Official Journal of the European Union, 327, 1-73.

Dušek J., Picek T. and Čížková H., 2008. Redox potential dynamics in a horizontal subsurface flow constructed wetland for wastewater treatment: Diel, seasonal and spatial fluctuations. Ecol. Eng., 34, 223-232. 
Dykyjová D. and Květ J., 1970. Comparison of biomass production in reedswamp communities growing in South Bohemia and South Moravia. In: IBP PT-PP Report No. 1, Czechoslovak Academy of Sciences, Praha, 71-79.

Ekstam B., Johannesson R. and Milberg P., 1999. The effect of light and number of diurnal temperature fluctuations on germination of Phragmites australis. Seed Sci. Res., 9, 165-170.

Ellenberg H., Weber H.E., Düll R., Wirth V., Werner W. and Paulissen D., 1992. Zeigerwerte von Pflanzen in Mitteleuropa 3., durchgesehene Auflage. Verlag Erich Goltze KG., Göttingen.

Furey P.C., Nordin R.N. and Mazumder A., 2004. Water level drawdown affects physical and biogeochemical properties of littoral sediments of a reservoir and a natural lake. Lake Reserv. Manage., 20, 280-295.

Gambrell R.P. and Patrick W.H., 1978. Chemical and Microbiological properties of anaerobic soils and sediments. In: Hook D.D. and Crawford R.M.M. (eds.), Plant Life in Anaerobic Environments, Ann Arbor, Michigan, 351-375.

Gasith A. and Hoyer M.V., 1998. Structuring role of macrophytes in lakes: changing influence along lake size and depth gradients. In: Jeppesen E., Søndergaard M., Søndergaard M. and Christoffersen K. (eds.), The Structuring Role of Submerged Macrophytes in Lakes, Springer New York, 381-392.

Hejný S., 1960. Ökologische Charakteristik der Wasser- und Sumpfpflanzen in den slowakischen Tiefebenen (Donau- und Theißgebiet), Vydavatel'stvo SAV, Bratislava, 480 p.

Hejný S. and Husák Š., 1978. Higher plant communities. In: Dykyjová D. and Květ J. (eds.), Pond Littoral Ecosystems: Structure and Functioning, Springer, Berlin, 23-64.

Hejný S. and Segal S., 1998. General ecology of wetlands. In: Westlake D.F., Květ J. and Szczepański A. (eds.), The Production Ecology of Wetlands, Cambridge University Press, Cambridge, 367-404.

Hellsten S. and Riihimäki J., 1996. Effects of lake water level regulation on the dynamics of aquatic macrophytes in northern Finland. Hydrobiologia, 340, 85-92.

Hellsten S., Marttunen M., Palomäki R., Riihimäki J. and Alasaarela E., 1996. Towards an ecologicallybased regulation practice in Finnish hydroelectric lakes. Regul. River., 12, 535-545.

Hill N.M., Keddy P.A. and Wiesheu I.C., 1998. A hydrological model for predicting the effects of dams on the shoreline vegetation of lakes and reservoirs. Environ. Manage., 22, 723-736.

Hroudová Z., 1988. Littoral Vegetation of the Rožmberk Fishpond and its Mineral Nutrient Economy, Academia, Praha, $112 \mathrm{p}$.

Hutchinson G.E., 1975. A Treatise on Limnology. Limnological Botany, Wiley, New York, Vol. III, 660 p.

Janauer G.A. and Wychera U., 2000. Biodiversity, succession and the functional role of macrophytes in the New Danube (Vienna, Austria). Arch. Hydrobiol. Suppl., 135, 61-74.

Káplová M., Keith R.E. and Květ J., 2010. The effect of nutrient level on plant structure and production in a wet grassland: a field study. Plant. Ecol., 212, 809-819.

Keddy P.A. and Reznicek A.A., 1986. Great Lakes vegetation dynamics: the role of fluctuating water levels and buried seeds. J. Great Lakes Res., 12, 25-36.

Kopáček J. and Hejzlar J., 1995. Semi-micro determination of total phosphorus in soils, sediments, and organic materials: a simplified perchloric acid digestion procedure. Commun. Soil Sci. Plan., 26, 1935-1946.

Krolová M., Čížková H. and Hejzlar J., 2011. Littoral zonation in a cove of Lipno Reservoir. Acta Musei Bohemiae meridionalis in České Budějovice - Scientiae naturales, 51, 57-72 (in Czech).

Krolová M., Čížková H. and Hejzlar J., 2012. Limits of development of littoral vegetation in a storage reservoir: Case study of Lipno Reservoir, the Czech Republic. Limnologica, 42, 165-174.

Květ J., Westlake D.F., Dykyjová D., Marshall E.J.P. and Ondok J.P., 1998. Primary production in wetlands. In: Westlake D.F., Květ J. and Szczepański A. (eds.), The production Ecology of wetlands, Cambridge University press, 78-139.

Lepš J. and Šmilauer P., 2003. Multivariate analysis of ecological data using CANOCO, Cambridge University Press, $284 \mathrm{p}$.

Lindström T., 1973. Life in a Lake Reservoir: Fewer Options, Decreased Production. Ambio, 2, 145-153.

McComas S., 2003. Lake and Pond Management, Guidebook, Lewis Publishers, Washington, 286 p.

Minář J., 1964. Changes of aquatic and littoral vegetation on Lipno Reservoir. In: Ježdík T. and Jeník J. (eds.), Vegetation Problems in the Construction of Water Reservoirs, Academia, Praha, 233-245 (in Czech). 
Moss B., 2008. The kingdom of the shore: achievement of good ecological potential in reservoirs. Freshw. Rev., 1, 29-42.

Nilsson C. and Keddy P.A., 1988. Predictability of change in shoreline vegetation in a hydroelectric reservoir, northern Sweden. Can. J. Fish. Aquat. Sci., 45, 1896-1904.

Partanen S. and Hellsten S., 2005. Changes of emergent aquatic macrophyte cover in seven large boreal lakes in Finland with special reference to water level regulation. Fennia, 183, 57-79.

Ponnamperuma F.N., 1984. Effects of flooding on soils. In: Kozlowski T.T. (ed.), Flooding and Plant Growth, Academic Press, Orlando, 10-46.

Richardson J.I. and Vepraskas M.J., 2000. Wetland Soils: Genesis Hydrology, Landscape and Classification, Lewis Publishers, USA, $432 \mathrm{p}$.

Scheffer M., 1999. The effect of aquatic vegetation on turbidity; how important are the filter feeders? Hydrobiologia, 409, 307-316.

Shoup D.E. and Wahl D.H., 2009. Fish diversity and abundance in relation to interannual and lakespecific variation in abiotic characteristics of floodplain lakes of the lower Kaskaskia River, Illinois. T. Am. Fish. Soc., 138, 1076-1092.

Šumberová K., Lososová Z., Fabšicová M. and Horáková V., 2006. Variability of vegetation of exposed pond bottoms in relation to management and environmental factors. Preslia, 78, 235-252.

ter Braak C.J.F. and Šmilauer P., 2002. CANOCO reference manual and CanoDraw for Windows user's guide: software for Canonical Community Ordination (version 4.5), Microcomputer Power, Ithaca, New York, $500 \mathrm{p}$.

Van der Maarel E., 1979. Transformation of cover-abundance values in phytosociology and its effects on community similarity. Vegetatio, 39, 97-114.

Vilmundardóttir O.K., Magnússon B., Gísladóttir G. and Thorsteinsson Th., 2010. Shoreline erosion and aeolian deposition along a recently formed hydro-electric reservoir, Blöndulón, Iceland. Geomorphology, 114, 542-555.

Wantzen K.M., Rothhaupt K.-O., Mörtl M., Cantonati M., G.-Tóth L. and Fischer P., 2008. Ecological effects of water-level fluctuations in lakes: an urgent issue. Hydrobiologia, 613, 1-4.

Weisner S.E.B. and Ekstam B., 1993. Influence of germination time on juvenile performance of Phragmites australis on temporarily exposed bottoms - implications for the colonization of lake beds. Aquat. Bot., 45, 107-118.

Welch N.H., Butler M.G., Carlson T.J. and Hanson M.A., 2003. Changes in macrophyte community structure in Lake Christina (Minnesota), a large shallow lake, following biomanipulation. Aquat. Bot., 75, 323-337.

Wetzel R.G., 1983. Limnology, second edition, Saunders College Publishing, Forth Worth, 767 p. 